\title{
Coaching High Potential Executives for Leadership Positions
}

\author{
Jitendra Mohan Pant
}

\begin{abstract}
The objective was to coach 25 executives identified by top management of a large integrated steel plant in India and prepare them for leadership positions as section heads or heads of departments. The journey of coaching over ten months brought distinct transformation in Fourteen attributes namely problem solving skills, root cause analysis, time management, goal setting and execution, learning from failures, self-confidence, self-drive and initiative, ownership, managing change, presentation skills, communication and listening skills, anger management, team building and leadership skills. The coaching process was a mix of one on one coaching sessions, and group coaching sessions, at monthly intervals, interspersed with project work done by participants each month. Feedback from superiors to keep track of the coachee's progress, evaluation test for assessing coachees, and Action Plan were other key elements of coaching. The coachees and their superiors were happy at the transformation reflected in improvement in performance at work.
\end{abstract}

Keywords - Coaching, Improvement, Leadership, Performance.

\section{INTRODUCTION}

Coaching concept in business has evolved from sports, arts like music and painting, and traditions of grooming and developing princes for becoming prosperous kings. India has a rich heritage of teacher-pupil relationship. Our epics of Ramayana and Mahabharata are replete with such examples like the coach Drona to the princes of Kauravas and Pandavas, Lord Krishna as mentor to the famed archer Arjuna, Rishi Vishwamitra and Rishi Vashist who trained the princes of Ayodhya including Lord Rama. During the Mauryan period, Chanakya was the acclaimed coach to Chandragupta Maurya. In Homer's Odyssey, Mentor was a faithful friend into whose care the world wandering hero Odysseus entrusted his son Telemachus, with the job of guiding the prince's development while his father was fighting in the Trojan war. Telemachus would be the future ruler of the kingdom and it was important that he be prepared.

Coaching is a practical, forward looking, and interactive way to help the coachee, who may feel lonely at times, achieve desirable results in their professional work. It is a powerful support system to keep the coachee motivated and moving in the right direction. The Coach observes the coachee impartially as an independent person, with no hidden agenda, and can provide honest and unbiased feedback which the coachee would miss otherwise. Coach provides an external perspective and enables the coachee to determine their own 'answers' and reach a better quality decision. Coach provides

Jitendra Mohan Pant is life coach. the support and empathy, listening actively to the coachee and becoming his or her sounding board. This helps the coachee in bouncing off his or her ideas on a more experienced person, who occasionally acts as the trainer, teacher and advisor.

\section{THE COACHING PROJECT}

Sunflag Iron and Steel Company, an integrated steel plant in India based in Bhandara, near Nagpur, in central India, is a professionally managed company manufacturing alloy steel, stainless steel, special steels for automobiles, railways, engineering, bearing industry and others, and is now developing products for defence and space. Top management is always looking for new ways of employee engagement, employee development and employee empowerment. As part of career planning, they had identified 25 executives in middle and lower middle management positions who based on their performance evaluation over consecutive years had shown glimpses of potential as future leaders in the organisation. The executives were from different departments namely Steel Melting Shop (5 persons), Blast furnace (3 persons), Direct Reduction Plant (1 person), Power Plant (2 persons), Rolling Mills (4 persons), Bright bar and Heat Treatment ( 3 persons), Crane shop (1 person), IT systems (1 person), Projects (2 persons), Human Resource department (2 persons), and Marketing (1 person).My job was to coach them, train them and mentor them so that they are ready to taking up senior leadership positions in the organisation as Heads of department or Section Heads.

\section{THE COACHING PROCESS}

The coaching process started in January 2019. I was the life coach and would make visits for four days at a stretch, once a month. During each monthly visit, I would have one on one sessions with all 25 executives. The sessions would be of 45 minutes each. The process would start at 8:45 am and continue late till $7 \mathrm{pm}$. For common topics and areas where I wanted to emphasise and teach them for building their concepts and fundamentals, I had common coaching and training sessions. Homework and project assignments were given during each visit which the coachee was supposed to complete before the next monthly visit. Feedback was taken from the coachee's reporting heads and seniors so that I could direct my coaching and training sessions accordingly. The feedbacks were taken in writing by sending the seniors a format on questions to be asked and the rating. After six months, an assessment test was taken which was 3 hour long comprehensive test aimed at understanding of concepts and their application in the work areas of the coachee. At the end of the 10 months coaching 
program, the coachees submitted a 30 page report on the way they applied their learning in their work areas and the improvements made by them.

\section{COACHING FLOW PROCESS}

\section{Professional Development}

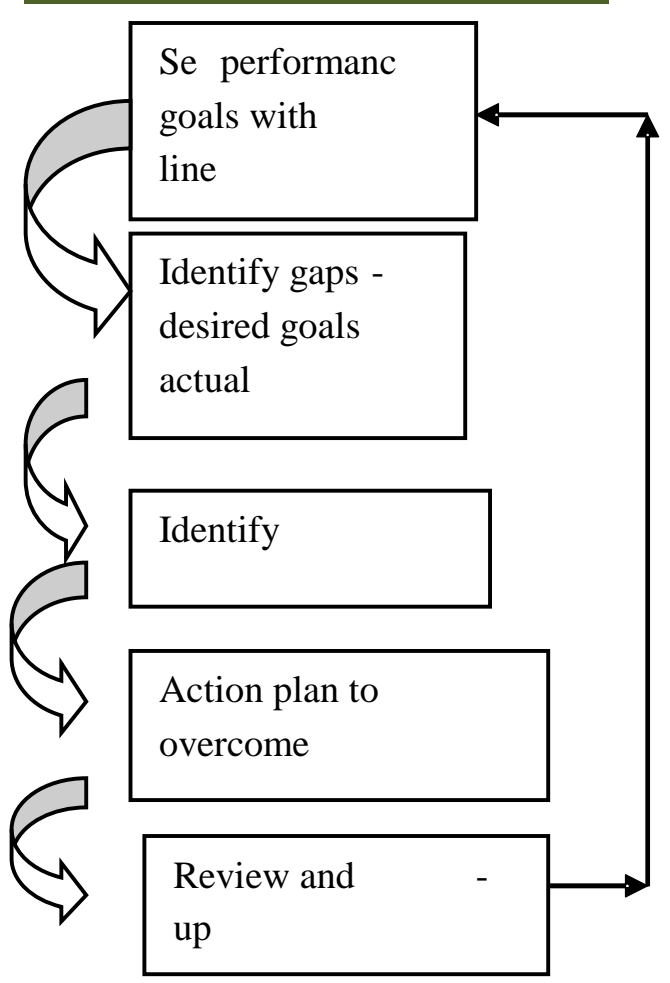

\section{Personal Development}

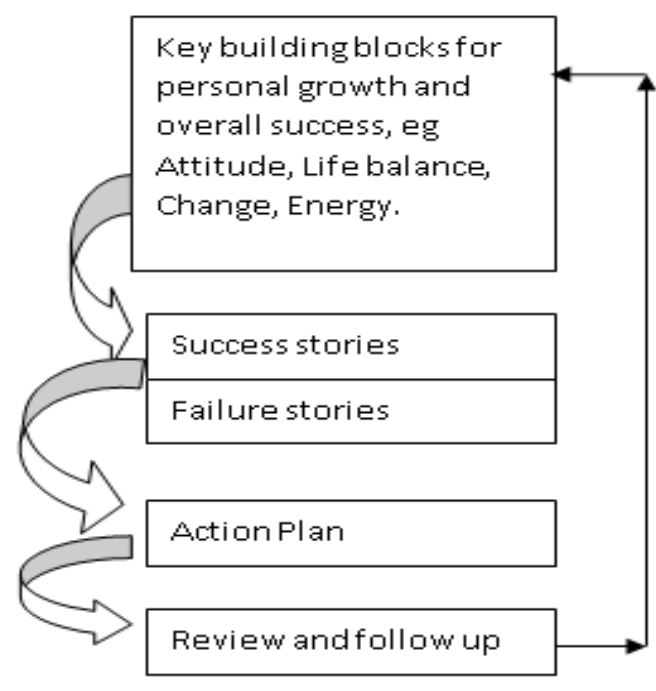

\section{ONE ON ONE COACHING SESSIONS}

The one on one coaching sessions with coachees held each month at the plant of the company covered the following:

\section{Professional goals}

o Setting goals.

- Action plan to achieve goals.

o Likely obstacles to achieve goals, and plan to overcome the constraints.

o Commitment level.

○ Execution of goals, progress and status.

Personal goals

o Setting goals.

- Action plan to achieve goals.

o Likely obstacles to achieve goals, and plan to overcome the constraints.

o Commitment level.

$\circ$ Execution of goals, progress and status.

\section{Success Journal}

○ Coachees maintained a success journal in which they would list their achievements and learning from success.

o Success would give coachees a sense of fulfilment and motivate them to do more.

\section{Failure journal}

o Coachees maintained a failure journal in which they would list each failure and learning from failure.

o Coachees learn from failures more than from success.

\section{Strong points}

o Coachees identify their strengths and work on them to make them stronger.

○ Coachees work at enhancing their competencies.

\section{Weak points}

$\circ$ Coachees identify their weak points and work on addressing them.

- Coachees are made to analyse the reasons for the weak point and work out a complementary system or sometimes a template driven way of managing weakness.

\section{Project work, homework, assignments and training} sessions

o Review and feedback on work completed and in progress.

$\circ$ Learning from training sessions and their application in coachee's work area.

The coachees were required to create a folder in google drive, One drive or drop box as per their convenience, and to name it Coach/JMP/Coachee/Name of Coachee. All files-ppt, doc, pdf, xls, audio files, video files, had to be uploaded by the coachee on this folder each month and the link shared with me. This way space would be saved in one's computer system, and 
the file sharing was easy as emailing heavy files is a problem.

\section{GROUP COACHING AND TRAINING SESSIONS}

The improvement themes which were common to all coachees were addressed through group coaching and training sessions. Group sessions allowed experiential learning, personality building and confidence development in speaking, presentation and convincing skills. The coachees enjoyed these sessions and expressed happiness in seeing their self-confidence surging through in every session.

The sessions were grouped into following three broad categories:

1. Self-development

2. Leadership skills

3. Problem solving skills

\begin{tabular}{|l|l|l|}
\hline $\begin{array}{l}\text { Self- } \\
\text { Development }\end{array}$ & Leadership Skills & $\begin{array}{l}\text { Problem Solving } \\
\text { Skills }\end{array}$ \\
\hline Who Am I? & $\begin{array}{l}\text { Competencies of } \\
\text { effective leaders }\end{array}$ & $\begin{array}{l}\text { Identifying and } \\
\text { defining problem }\end{array}$ \\
\hline $\begin{array}{l}\text { Unleash the } \\
\text { power within }\end{array}$ & $\begin{array}{l}\text { Leadership styles } \\
\text { and behaviour }\end{array}$ & $\begin{array}{l}\text { Problem solving } \\
\text { steps }\end{array}$ \\
\hline $\begin{array}{l}\text { Speaking } \\
\text { Skills }\end{array}$ & $\begin{array}{l}\text { Communication } \\
\text { Skills }\end{array}$ & $\begin{array}{l}\text { Analysing } \\
\text { problem, tools }\end{array}$ \\
\hline $\begin{array}{l}\text { Spoken } \\
\text { English }\end{array}$ & Listening skills & Brainstorming \\
\hline $\begin{array}{l}\text { Confidence } \\
\text { building }\end{array}$ & Interpersonal skills & $\begin{array}{l}\text { Data analysis, 7 } \\
\text { QC tools }\end{array}$ \\
\hline $\begin{array}{l}\text { Overcoming } \\
\text { fear }\end{array}$ & Time Management & $\begin{array}{l}\text { Reduction of time, } \\
\text { changeover time }\end{array}$ \\
\hline $\begin{array}{l}\text { Change } \\
\text { management }\end{array}$ & $\begin{array}{l}\text { Conflict } \\
\text { management }\end{array}$ & $\begin{array}{l}\text { Root cause } \\
\text { analysis }\end{array}$ \\
\hline $\begin{array}{l}\text { Ownership, } \\
\text { Self-drive and } \\
\text { initiative }\end{array}$ & $\begin{array}{l}\text { Presentation Skills, } \\
\text { Presentation on } \\
\text { Improvements }\end{array}$ & $\begin{array}{l}\text { Process map, } \\
\text { value stream } \\
\text { mapping }\end{array}$ \\
\hline $\begin{array}{l}\text { Anger } \\
\text { management }\end{array}$ & $\begin{array}{l}\text { Motivating and } \\
\text { influencing }\end{array}$ & Waste walk \\
\hline Personality & Motivating Self & Control charts \\
\hline $\begin{array}{l}\text { Continual } \\
\text { learning }\end{array}$ & $\begin{array}{l}\text { Teaming for } \\
\text { Excellence }\end{array}$ & $\begin{array}{l}\text { Process Capability } \\
\text { Studies }\end{array}$ \\
\hline $\begin{array}{l}\text { Willingness to } \\
\text { learn }\end{array}$ & Delegation & Six thinking hats \\
\hline
\end{tabular}

\section{TRANSFORMATION}

There was appreciable change for the better in all the coachees as shown in the following table and radar chart.

The transformation was incremental, in some more than others, but the positive change was perceived in all coachees not only by me but also by their immediate superiors, heads of departments and super seniors. This was confirmed through formal feedback by superiors, and was also reflected in improvement in their performance, attitude and behaviour at work. The mean change in coachees attitude, approach, behaviour and performance in the following parameters in a scale of 1 to 10 , with 1 as Insignificant change and 10 as Excellent change, is depicted in the radar chart shown here.

\begin{tabular}{|l|c|}
\hline & $\begin{array}{c}\text { Level of } \\
\text { Change }\end{array}$ \\
\hline Self-Development & \\
\hline Ownership & 7 \\
\hline Managing Change & 7 \\
\hline Speaking skills & 6 \\
\hline Confidence and self-esteem & 7 \\
\hline Anger management & 9 \\
\hline Self-drive and initiative & 8 \\
\hline & \\
\hline Leadership & \\
\hline Leadership Skills & 7 \\
\hline Review and monitoring skills & 6 \\
\hline Time Management & 8 \\
\hline Delegation & 8 \\
\hline Presentation skills & 7 \\
\hline Motivating team & 7 \\
\hline Communication and listening skills & 7 \\
\hline & \\
\hline Problem Solving & 9 \\
\hline Identifying and defining Problem & \\
\hline Analysing problem, Data Analysis & \\
\hline Root Cause Analysis & \\
\hline Execution of improvements & \\
\hline & \\
\hline & \\
\hline & \\
\hline & \\
\hline & \\
\hline & \\
\hline & \\
\hline & \\
\hline & \\
\hline & \\
\hline & \\
\hline
\end{tabular}

\begin{tabular}{|c|c|}
\cline { 2 - 2 } \multicolumn{1}{c|}{} & $\begin{array}{c}\text { Level of } \\
\text { Change }\end{array}$ \\
\hline Insignificant change & 1 \\
\hline Mild change & 2 \\
\hline Minor change & 3 \\
\hline Fairly Good change & 4 \\
\hline Average Change & 5 \\
\hline Good Change & 6 \\
\hline Moderately Good Change & 7 \\
\hline Very Good Change & 8 \\
\hline Extremely Good Change & 9 \\
\hline Excellent Change & 10 \\
\hline
\end{tabular}




\section{Self Development-Level of Change}
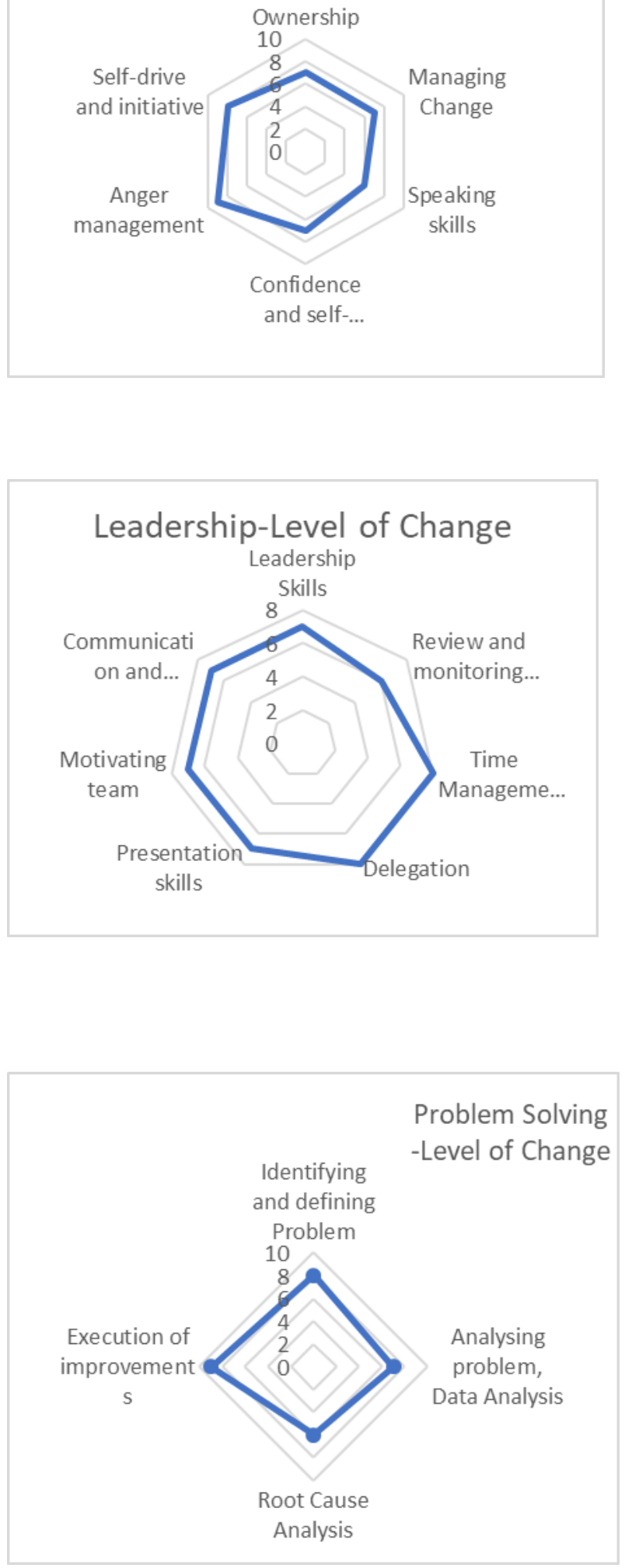

[1]The Toyota Way by Jeffrey K Liker

[2]2. Fortune at the bottom of the pyramid by C. K. Prahalad

[3] The Goal by Eliyahu M. Goldratt

[4]Three box solution by Vijay Govindrajan

[5]Execution By Larry Bossidy \& Ram Charan

[6] Six thinking hats by Edward de Bono

[7] Straight from the guts by Jack Welch

[8]Coaching for Performance: The Principles and Practice of Coaching and Leadership by John Whitmore

[9]Executive Coaching by Sue Liburd.

\section{Jitendra Mohan Pant, Author}

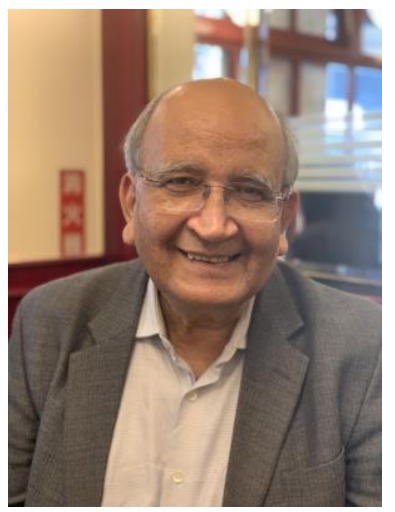

Born in Allahabad, India, in the year 1951, Jitendra M. Pant is a graduate in mechanical engineering (19720 from Indian Institute of Technology (I.I.T), Delhi, India; a post graduate in production and industrial engineering (1974) from I.I.T Delhi and a diploma in Marketing Management from UBS, Chandigarh.

He has over four decades of experience in industry and consultancy and specialises in

$\mathrm{He}$ is a mentor, life coach, consultant and trainer, for personal and professional development, in areas of life coaching, individual and personal mentoring, and work-related coaching.

The domain covers career transitions, self-management and selfimprovement, performance management, productivity, quality and HR initiatives, functional knowledge in operations and project management, entrepreneurial leadership and enterprise growth. 
The change is brought about through a blend of coaching and mentoring sessions, and learning and development workshops, both on line and face to face meetings. The spectrum covered is diverse from industry and business owners, and young entrepreneurs, of micro, small and medium enterprises (MSME) and start up units, to professionals working in MNCs and family managed enterprises, in manufacturing and services.

Mr. Pant is an avid lifelong learner, self-driven, and professionally engaged in training, writing, mentoring and coaching assignments.

Following books written by him are available online from pothi.com, flipkart.com and amazon.in.

\section{S: First Vital Step Towards Operations Excellence}

A Practice Oriented Book for 5S Awareness \& Implementation.

5S: Foundation for Operations \& Personal

Excellence- A Practice Oriented Text With Online and

Site support

Time Management For higher personal productivity

\section{Lessons from uncommon thoughts}

\section{Problem Solving}

Simple tools and techniques which everyone can understand

\section{Confidence Building}

For personal happiness

No

Say No, Be Happy

\section{Websites}

www.jemsconsultancy.com

www.jmpantcoach.com

www.betterthanbeforesolution.com 